\title{
Challenges for foreign companies in China: implications for research and practice
}

\author{
Fabian Jintae Froese ${ }^{1,2} \cdot$ Dylan Sutherland ${ }^{3} \cdot$ Jeoung Yul Lee ${ }^{1,4} \cdot$ Yipeng Liu $^{5}$. \\ Yuan Pan $^{2}$
}

Published online: 22 August 2019

(C) Springer Nature Limited 2019

\begin{abstract}
As a large country with great development potential, China has been one of the most popular foreign direct investment destinations. However, foreign companies increasingly face a variety of challenges especially during the "soft-landing" of the Chinese economy and amidst anti-globalization tendency. Based on a comprehensive review of the extant literature, we provide a critical overview of some of the key challenges for foreign companies in China, focusing on two challenges related to the business environment, namely regulatory and cultural challenges, and two management challenges, namely innovation and human resource management. We provide managerial implications and outline directions for future research.
\end{abstract}

Keywords International business $\cdot$ China $\cdot$ Multinational enterprise $\cdot$ Innovation · Human resource management $\cdot$ Culture $\cdot$ Strategy $\cdot$ Foreign companies

\section{Introduction}

In November 1971, the Times magazine marked its cover page with "The Chinese Are Coming", but back then, few would have expected the Chinese to have come quite as far as where they are today. Within five decades, China has undergone an economic miracle, rising from one of the least developed countries in the world to becoming its second largest economy. In 2018, the GDP of China was about 13.46

Jeoung Yul Lee

jeoungyul@hongik.ac.kr

1 National Research Base of Intelligent Manufacturing Service, Chongqing Technology and Business University, Chongqing 400067, China

2 University of Göttingen, Göttingen, Germany

3 Durham University, Durham, UK

4 School of Business Management, Hongik University, Sejong 30016, South Korea

5 University of Reading, Reading, UK 
trillion U.S. dollars, with an annual 6.6 percentage growth (IMF 2018), ranking it between the U.S. and Japan in size. Although the estimated GDP growth rate for 2019 is expected to slow down to 6.2\% (IMF 2018), it still indicates huge economic expansion.

As a large country with great development potential, China has attracted enormous volumes of foreign direct investments (FDI). It has been one of the most popular foreign direct investment destinations since the initiation of its economic reforms (Wu and Burge 2018; Zhang et al. 2016b). While in the 1980s domestic investment was of great significance, FDI became much more important over the 1990s, and increasingly has contributed to China's overall economic growth (Wu and Burge 2018). By the end of 2017, 136,997 foreign-invested companies were registered in China (NBSC 2018). In 2018 alone, 60,533 foreign-invested enterprises were newly established, and 134.97 billion U.S. dollars of foreign capital was invested in China (MOFCOM 2019), among which the U.K and Germany were distinct with $150.1 \%$ and $79.3 \%$ annual investment increases, respectively (MOFCOM 2019). Foreign companies have been and will continue to be important actors in the Chinese market.

There are many opportunities that foreign companies can take advantage of, including the large and fast-growing domestic market, an improving institutional environment, various investor-friendly policies in regional and centrally controlled special economic and high-tech development zones (Wu and Burge 2018), an ever improving quality of human resources (Ma et al. 2016), and better infrastructure. Recent national nationally recorded development data illustrate an optimistic future. In 2017, China invested 12.59 billion U.S. dollars in transportation infrastructure, 3.02 billion in energy and 1.43 billion in water, roughly equal to 4, 2, and 29 times to India respectively (World Bank 2019). Such impressive investments promise a better developed industrial society which is a good foundation for further business, human and social development. Nevertheless, the most attractive part of China is probably its sheer market size. Thanks to the 1.4 billion population, China has become the largest market for many products. In 2017, Volkswagen sold $41.58 \%$ of its passenger cars in the Chinese market (Volkswagen 2017), and many other giant multinational enterprises (MNEs) such as Nestlé and L'Oréal also reported their highest growth in China compared to other regions. Moreover, China can provide a good environment for exciting new business possibilities in the domestic market as a digitally advanced country. The thriving digitalization in China offers opportunities for foreign companies to break the fences and penetrate the market or access resources with new business models. For instance, L'Oréal took the chance and evaluated its digital sales with "very good e-commerce results" (L'Oréal 2017, p. 51).

Despite these opportunities, foreign companies increasingly face a variety of challenges especially during the "soft-landing" of the Chinese economy. Perhaps due to the clear signals in 2018 of the anti-globalization tendency, the IMF forecasts decreases in some of the main economic factors in years ahead, not only in China but also in many other major economic entities (IMF 2018). The increasingly unfavorable international environment will have significant influences on foreign companies in China, such as causing fiercer competition from local companies who shift back to the domestic market. Another notable disadvantage that foreign companies cannot ignore is the liability of being outsiders. A very recent example was 
the backlash against the Italian luxury brand Dolce and Gabbana after it launched an advertisement with unflattering stereotypes. The founders of the brand apologized for delivering offensive messages due to "cultural misunderstandings" (BBC 2018), again confirming the importance of gaining local knowledge.

Doing business in a foreign country is not an easy task, and the dynamic Chinese market contributes to an even more challenging environment. Despite its impressive economic development, China is still a transitional economy, as it is arguably still moving from a position were few market supporting institutions existed (i.e., a centrally planned economy). Thus, it may still be problematic to apply management approaches from advanced Western countries in China (Warner 2009; Zhao and Duc 2012). This calls for more novel and contextualized research. Based on a review of the extant literature, we provide an overview of some of the key challenges for foreign companies in China, and provide directions for future research and business practice. Building on international business (IB) research and recent business developments in China, we focus on two key challenges related to the business environment, namely regulatory and cultural challenges, and two key management challenges, namely innovation and human resource management.

\section{Regulatory challenges}

Foreign businesses in China face government, legal, and regulatory challenges on two main fronts. First, China is an emerging market, characterized by a comparatively weak and fast evolving judicial and regulatory institutional environment. There is great flux in regulatory change across a broad range of spheres, including: environmental regulation and pollution prevention (He et al. 2016); capital/financial sector regulation (Zhang et al. 2016a); housing and real estate regulation (Glaeser et al. 2017); labor markets (Chang and Cooke 2015); and digital media content (Han 2016), to name but a few areas. Related government procedures, moreover, are generally less transparent. This can mean that relatively standard everyday tasks, like obtaining permit and product approvals, for example, may potentially become a drain on management resources.

Second, and arguably of far greater importance owing to their asymmetric impacts, local and central level governmental actors can potentially exploit local institutional fragility and regulatory flux to preferentially favor and support domestic firms. Indeed, China has long espoused ambitious domestic industrial policies to nurture national champions (Sutherland 2003). The policy to build a "national team' of around one hundred large internationally competitive business groups, for example, follows an East Asian model of development (particularly Japanese and South Korean industrial policies, with their large keiretsu and chaebol groups). This Chinese development strategy actually dates back to the early 1980s (Guest and Sutherland 2009). Its evolution over four decades is now reaching its zenith. The current China 'Manufacturing 2025' policies, for example, target ten specific industries (including new advanced information technology, automated machine tools and robotics, aerospace and aeronautical equipment, maritime equipment and high-tech shipping, modern rail-transport equipment, new-energy vehicles and 
equipment, power equipment, agricultural equipment, new materials, and biopharma and advanced medical products). In areas such as new electric vehicles and battery technology, semiconductors, solar panels/modules and wind power, interventions have been extensive, ongoing and highly prominent (World Bank \& DRC 2013). ${ }^{1}$

One of the greatest geopolitical issues of our day, the China-US relationship, is intimately tied to these ongoing industrial policies. Ongoing trade negotiations in early 2019, for example, centered on Chinese state subsidies, government directed credit (via the state-controlled banking system) and public procurement, as well as forced technology transfer. In short, China appears to be using domestic legal, regulatory and government interventions to favor its domestic firms. Policy-makers, moreover, appear strongly committed to this type state orchestrated capitalism. In current trade negotiations, for example, which have been likened by US negotiators to "pulling teeth" owing to China's "stonewalling on market access", only "cosmetic, non-impactful offers" on important matters like subsidies have been made. In the European Union, like the US, sentiment has also swung strongly against Chinese interventions. KUKA's acquisition by Midea Group in 2016, for example, sparked a national debate within Germany leading to a significant change in mindset, led by Angela Merkel, of European Union leaders towards China. Greater reciprocity from China (i.e., market access, fewer institutional and regulatory blocks on foreign MNEs) has become a key issue, as has a strategic response from Europe. Recent EU attempts led by France and Germany, for example, to create a European champion in train-making (and engage with China using similar strategic approaches) have been launched. In early 2019 efforts were made by France and Germany to merge the train manufacturing operations of Alstom (France) and Siemens (Germany). This was a direct response to Chinese industrial support for CRRC (the biggest train maker in the world). The merger was blocked, however, by the EU's very own competition commission. Margarethe Vestager, its head, has however acknowledged that it is "more and more obvious" that the degree of market openness between the EU and China is very much "an asymmetrical thing" (Toplensky n.d.). As a result European leaders are now looking to reform competition rules to create a system that may be more in line with their own strategic industrial policy (i.e., China's state capitalism model is drawing a strategic response from Europe). Current geopolitical interactions between the US, EU and China testify to deep concerns about asymmetric industrial interventions that China has engaged into facilitate firm-level catch-up.

All firms, both domestic and foreign alike, face and may equally respond to domestic institutional voids. While these are interesting to understand, arguably of greater interest today is the question of how Chinese state industrial policies and government intervention interact with the legal and regulatory environment to give

\footnotetext{
1 Semiconductors, for example, are reported to have received over $\$ 150$ billion in government subsidies alone. According to the US President's Council of Advisors on Science and Technology, Chinese industrial policies in this sector " pose real threats to semiconductor innovation and US national security"' (Lucas 16/01/2017). New battery technologies have similarly received great support, with large stateowned groups like CATL now emerging as one of the largest players on the world stage (Sanderson, Hancock, and Lewis 05/03/2017). Similarly, support (and overcapacity) in wind and solar- power sectors have been prominent to date.
} 
domestic big businesses a leg-up over non-domestic rivals. To what extent do such policies actually discriminate against foreign competitors in China, putting them at a disadvantage? How effective, if at all, is current Chinese industrial policy to force technology transfer? Why might China be in a good position to orchestrate such a strategy? Do particular industries, like renewables, a recipient of Manufacturing 2025 , more strongly benefit from these policies or are they more widely diffused? In short, how justified are European and US policy-makers in making their current claims against China? To answer these questions, more detailed industry level studies are required.

\section{Cultural challenges}

China has a long history stretching over 5000 years. Chinese culture, unsurprisingly, has had a profound influence on Asia. Traditionally, under the influence of Confucian, Taoist, and Buddhist faiths, Chinese culture generated a rich and profound system of values (Leung 2010) which have uniquely evolved in each region/municipality of China (Kwon 2012). Culture can be defined as distinguished values, norms, behaviors, rules, and psychological and systematic assumptions among groups of people (Hofstede 1991). International Business (IB) has been about the various operations of businesses in the global arena, where different cultures among groups of people can both conflict and/or blend together with one other. However, before Hofstede's (1980) seminal study on work-related values employing data based on employee attitude surveys from 88,000 employees of IBM subunits in forty countries, there was no appropriate cultural index that could be studied by IB scholars. However, after the development of Hofstede's four cultural dimensions, and later Kogut and Singh (1988) cultural distance index, providing the first measures of cultural differences between countries, there has been a quantum leap and flourishing of IB studies based on these pioneering works. IB scholars now commonly undertake research on the international activities of MNEs across countries that have different cultures, to explore how these influence directly and indirectly critical decision-making, headquarter resource allocation, global network and embeddedness relationships, and MNE' organizational performance (e.g., Ambos and Ambos 2009; Dellestrand and Kappen 2012; Zeng et al. 2013).

While IB scholars have mainly studied cultural phenomena in the context of national cultural dissimilarities between home and host countries, there has been lesser attention given to subnational cultural dissimilarities within countries, and China specifically (e.g., Kwon 2012; Ma et al. 2013a, b; Tung et al. 2008). Tung (2008, p. 41) even emphasizes that "[g]iven the growing diversity of workforce within a country, intra-national variations can often be as significant as crossnational differences." Recently, the volume of studies on within-country cultures or cultural differences has increased. To empirically explore the work values of employees in China, for example, Kwon (2012) applies Hofstede's national cultural dimensions to measurements of subnational cultural variation within mainland China. Kwon finds there are differences in subnational cultures between Shenzhen (a southern region of China) and Taiyuan (a middle region of China). Ma et al. 
(2013b), moreover, report that intra-country dissimilarities are linked with foreign subsidiary outcome differentials in China. However, an issue with previous studies on national and subnational cultural differences is that they seldom investigate the interplay between national and subnational cultural differences, particularly, when foreign MNEs operate in China. One recent study, however, has contributed to this culture related literature by emphasizing cultural differences at both the within- and cross-country levels, exploring how these levels concurrently affect headquarters resource allocation for innovation transfer between sending and receiving subsidiaries in China (Miao et al. 2016).

To date, limited studies have explored the effects of within-country and/or cross-country cultural differences. Comparative cultural studies between China and other countries (e.g., India), moreover, can make meaningful contributions to future research and allow for more generalizability. Also, when investigating subnational cultures, scholars may expand their understanding by using other cultural frameworks such as the GLOBE study (House et al. 2004), Ingelhart's World Value Survey (1997), the Schwartz Values Survey (1994) and the like. Finally, these within-country and cross-country cultural differences can affect subsidiary staffing and cultural friction in local subsidiaries of foreign companies in China; thus such research may have important applications and use (Singh et al. 2019).

\section{Innovation management challenges}

Innovation management in China is an important topic for both foreign firms and domestic stakeholders. It has been manifested largely through collaborative partnerships between foreign firms and domestic ones (Collinson and Liu 2019) in the form of joint ventures (Zhou and Li 2008) in the last four decades. In the form of international partnerships, learning from collaboration partners (Tsang 2002) can contribute to capacity building and industry upgrading (Herrigel et al. 2013). Despite many joint ventures facilitating knowledge, learning, and gaining experience in the development of innovation capabilities (Zhao and Anand 2013), foreign partners largely prefer not to share the core of innovation with Chinese domestic partners. This is in part due to the lack of intellectual property rights protection. Furthermore, when regulatory frameworks allowed, joint ventures tend to be converted into foreign wholly-owned subsidiary in China (Puck et al. 2009). In this way, foreign firms may develop and protect innovation within organizational boundaries. In addition, China's rapid economic development demands the transformation from "Made in China" to "Created in China", in order to move up the global value chain in global competition. Importantly, China's innovation challenge is to overcome the middleincome trap to become an innovation economy (Lewin et al. 2016).

Two emergent approaches in relation to innovation management have attracted significant attention in both scholarly inquiry and public policy initiatives, namely (1) Chinese cross-border mergers and acquisitions (M\&A) for innovation and technological upgrading; (2) overseas high-skilled talent returning to China. First, Chinese firms responded to the national "Go Abroad" strategy via M\&A in the pursuit of acquiring advanced technology (Liu and Woywode 2013). This still nascent 
phenomenon put challenges to Chinese acquirers, because they may not possess the necessary absorptive capability or lack understanding of institutional arrangements in host countries in managing strategic assets, such as brands and technologies (Liu et al. 2018). In China's globalization endeavors, one key motivation is learning. But the effective innovation management and knowledge transfer requires boundary spanners with pertinent experience and ability (Liu and Meyer 2018). In other words, human side psychological micro-foundations can significantly affect innovation management in collaborative partnerships between foreign firms and their Chinese counterparts (Liu et al. 2017). Second, overseas high-skilled talent returning to China became a national strategy (Wang and Liu 2016). Not only can returnees start their own entrepreneurial and innovative ventures (Liu and Almor 2016), but they can also join research institutions or universities and foreign firms in China to upgrade their research capacities (Zhang et al. 2013). Returnees may contribute to innovation and entrepreneurship on organizational-level (Liu 2017) and regionallevel (Xing et al. 2018). Notably, returnees can even compensate the lack of university capability in China to foster innovation and regional entrepreneurship (Liu and Huang 2018). The presence of foreign firms and their interaction with returnee and domestic firms can contribute to innovation management.

In linking the global strategy and innovation management domain, we argue emerging economies may offer an experimental lab to cultivate new innovative ideas while addressing the global challenges faced by both foreign firms and domestic counterparts. For instance, reverse innovation may benefit both China and the rest of the world by delivering 'value for many' besides 'value for money' (Govindarajan and Ramamurti 2011). The rapid deployment of technological advancement, such as Artificial Intelligence and Big Data in the age of digital economy, provide opportunities for both Chinese and foreign firms to transform and innovate (Zeng 2018). We suggest China may lead innovation, even break-through innovation given the strong commitment from governments; foreign firms need to rethink their innovation strategy in order to succeed in this dynamic digital economy (Li 2019; Ning et al. 2017). Nevertheless, China and the rest of the world ultimately hold a shared destiny together and innovation in China will potentially bring co-prosperity for the world. Collaboration and cooperation will be the way forward.

\section{Human resource management challenges}

Along with the development of the Chinese economy, HRM has become an increasingly important topic in China. Foreign capital brought modern HRM into the Chinese market, leveraging from foreign-owned enterprises (FOEs) to joint ventures (JVs) and further to large domestic companies (Warner 2009). Foreign companies introduced formalized high-performance HR practices, which have been attractive to Chinese employees (Ma et al. 2016; Zhang et al. 2016b). The transitional Chinese employment system has gradually changed from capitaloriented to talent-oriented (Zhao and Du 2012) after several decades of industrialisation. The Chinese HRM system is a hybrid model (Ma et al. 2016) with an "ongoing process of paradoxical integration" (Warner 2009, p. 2183). There 
are theoretical and practical necessities to develop intensive research in HRM responding to up-to-date Chinese mechanisms of economic and social transition (Zhao and Du 2012).

Attracting and retaining highly qualified personnel has been one of the main challenges for foreign companies in China (Dewhurst et al. 2012; HitotsuyanagiHansel et al. 2016; Ma et al. 2016; Zhang et al. 2016b). While the number of college graduates is abundant, (more than seven millions students graduated in 2017) the number of highly qualified talent sought by foreign firms, particularly at higher managerial levels, remains scarce (Han and Froese 2010). In consequence, highly qualified talent can demand high pay and can easily switch jobs, resulting in high employee turnover rates (Dewhurst et al. 2012; Han and Froese 2010; Zhang et al. 2016b). This is costly for foreign companies. Although foreign companies offer desirable jobs with higher pay (Wu and Burge 2018), Chinese talent in the new era require more than high pay, including career opportunities, training opportunities, and job autonomy (Froese 2013; Froese and Xiao 2012). Meanwhile, Chinese domestic companies have imitated the HRM system of foreign companies and become attractive employers (Dewhurst et al. 2012). While foreign companies relied on expatriates in the past (Han and Froese 2010; Pak et al. 2019), Western expatriates are less willing to move to China (Dewhurst et al. 2012), making it even more difficult for foreign companies to attract talent. While foreign companies struggle, due to country of origin effects (Froese and Kishi 2013; Zhang et al. 2016b), Western companies may have fewer difficulties compared to their Asian counterparts (Froese and Kishi 2013). More research is needed to better understand how foreign companies can become more attractive to Chinese job candidates and how they may retain talent.

Increasing diversity is another emerging challenge for domestic and foreign companies alike. The demographic characteristics of the Chinese domestic labor force are changing. China is rapidly becoming an aging society. The Chinese fertility rate was 1.6 children per female in 2016 (Word Bank 2019), far below the conventional replacement fertility rate (approximately 2.1). Most existing HRM research within the Chinese context focuses on the relatively younger generations. Given substantial value differences between generations in China (Froese 2009), little is known about how companies can manage an age-diverse group of employees. Another diversity challenge comes from the endogenous complexity of the Chinese labor market. Regional imbalance is a notable characteristic of Chinese HRM practices (Zhao and Du 2012). Given the fact that current foreign companies agglomerate in certain regions (NBSC 2018), it will be theoretically and practically interesting to discover more relationships between the diverse regional conditions and the effectiveness of HRM in foreign companies. Meanwhile, within foreign companies, their expatriated talent also are becoming more diverse. The rise of non-traditional expatriates in China (Kang et al. 2017) suggests challenges in supporting such flexible human allocation strategies in foreign companies (Kang et al. 2017). Apart from international mobility, internal mobility of Chinese workers may become an ever more important issue. 


\section{Conclusion}

While China is an attractive market for foreign firms, our review reveals some of the key challenges of doing business in China. Table 1 provides a summary of these as well as the implications for future research and practice.

First, the business environment in China has become increasingly challenging for foreign MNEs in the past decade. The Chinese regulatory institutional environment involves a flux across a broad range of areas (i.e., Chang and Cooke 2015; Glaeser et al. 2017; Han 2016; He et al. 2016; Zhang et al. 2016a). The Chinese legislative system, moreover, lacks transparency and favors domestic firms, particularly in some high-tech related industries such as renewable energies and robotics (Sutherland 2003). Many current geopolitical conflicts between China and US/EU are related to such asymmetrical industrial policies. Thus, further research is needed to better understand the causes and consequences of these changing industrial policies. Foreign MNEs are advised to invest in human resources and political connections ( $\mathrm{Li}$ et al. 2018) to influence policies and/or find ways to deal with new policies.

Second, the cultural environment is a critical factor complicating business for foreign firms in China. Although many scholars have researched cultural differences (e.g., Froese 2013; Hofstede 1980; House et al. 2004) and the role of cultures in influencing the operations of MNEs (e.g., Ambos and Ambos 2009; Dellestrand and Kappen 2012; Zeng et al. 2013), within-country cultural dissimilarities are relatively less discussed (Tung 2008). Given the cultural and regional complexities in China (Kwon 2012), it is not surprising to find subnational cultural differences within the country (e.g., Kwon 2012; Ma et al. 2013b). Future research is encouraged to investigate the influence of within-country and crosscountry cultural differences on leadership, staffing, and strategic management of foreign subsidiaries in China. In addition to localization (Bader et al. 2017; Hitotsuyanagi-Hansel et al. 2016), foreign MNEs are advised to consider regional differences in their staffing strategies.

Third, foreign firms in China also come across significant management challenges, notably innovation management. Whereas China used to absorb knowledge from foreign MNEs through international collaborations (Collinson and Liu 2019; Herrigel et al. 2013; Ning et al. 2017; Zhao and Anand 2013), it now encourages home-grown innovation by launching international M\&As and attracting high-skilled returnees. Consequently, foreign MNEs need to consider the new aspects of innovation management, such as micro-foundations in collaborative relationships with Chinese partners or the presence of indigenous innovation. As an emerging economy with abundant resources, China may lead innovation in the digital era. Foreign MNEs may want to learn from China via collaborations with local partners and setting up R\&D centers in China. More research is needed to better understand how foreign MNEs can learn from foreign subsidiaries through coopetition and innovation in China.

Finally, HRM has been one of the top management challenges for foreign MNEs. Foreign companies have difficulties in attracting and retaining highly 


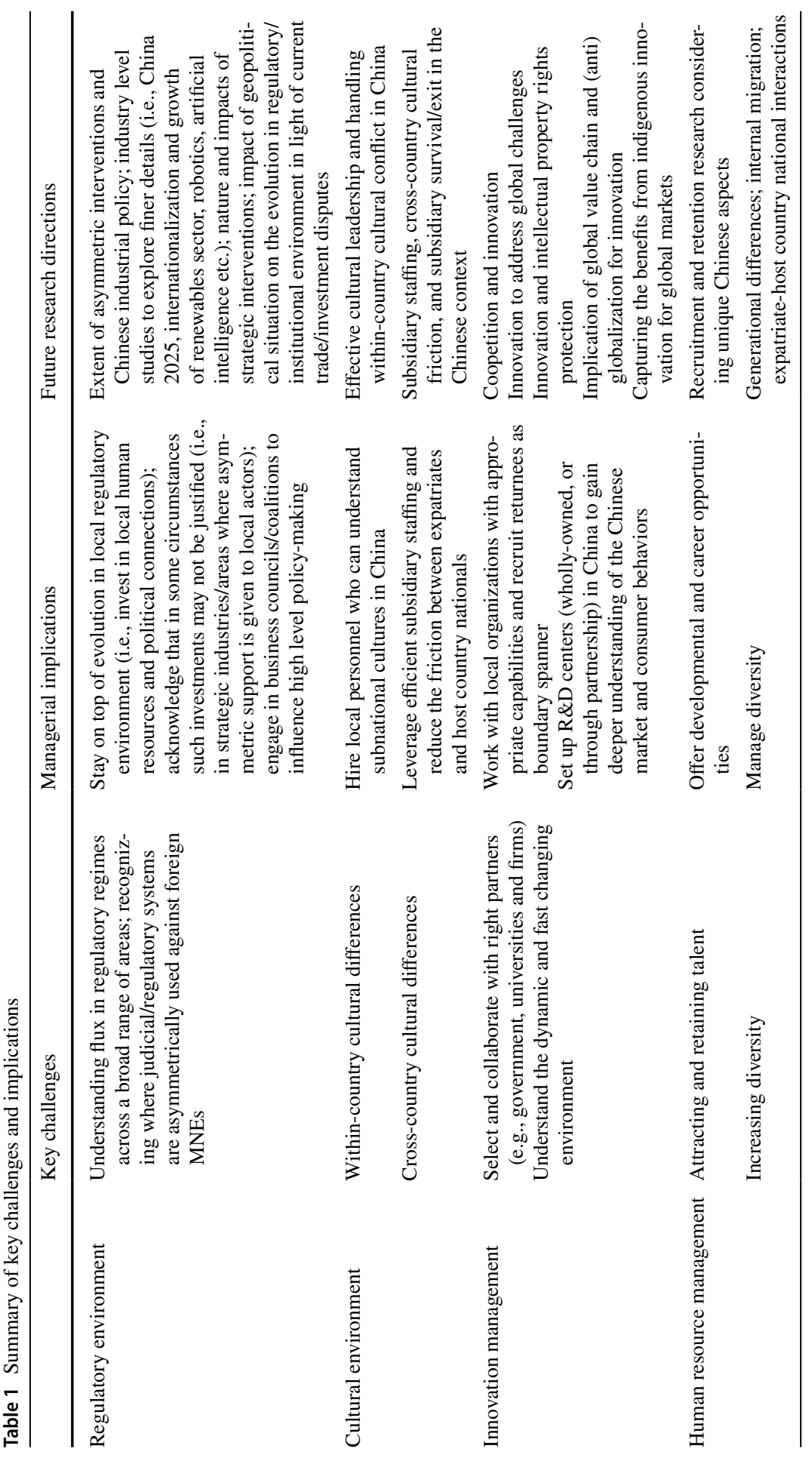


qualified talent in China (Dewhurst et al. 2012; Han and Froese 2010; Ma et al. 2016; Zhang et al. 2016b). The situation is likely to continue, if not worsen, in the coming years, owing in part to the changing demographic situation. Evolving demographic and regional differences are likely to bring more diversity to the workforce. Already being familiar with these challenges, MNEs from Western industrialized countries may be in better positions to manage such diversity (Bader et al. 2019; Kemper et al. 2016, 2019). Chinese companies might learn from Western MNEs regarding how to deal with an increasingly diverse workforce (Kemper et al. 2019). Foreign MNEs are advised to better understand the needs of Chinese talent and accordingly modify their HRM to attract and retain their employees (Froese 2013). Given these complex and unique characteristics, more research is needed to better understand talent management in China.

In summary, China presents great opportunities but also major challenges for foreign MNEs. In this article, we have reviewed some of these key challenges, possible managerial counter strategies and identified avenues for future research. To be successful in China it is essential for foreign MNEs to understand the unique business environment and gain internal legitimacy. To achieve these goals, foreign MNEs are encouraged to engage with the local environment, hire local talent, and nurture important connections. By doing so, the scope of understanding Chinese management by foreign MNEs may be further improved.

\section{References}

Ambos, T. C., \& Ambos, B. (2009). The impact of distance on knowledge transfer effectiveness in multinational corporations. Journal of International Management, 15(1), 1-14.

Bader, A. K., Froese, F. J., Achteresch, A., \& Behrens, S. (2017). Expatriates' influence on the organizational commitment of host country nationals in China: The moderating role of individual values and status characteristics. European Journal of International Management, 11(2), 181-200.

Bader, K., Kemper, L., \& Froese, F. J. (2019). Who promotes a value-in-diversity perspective: A fuzzy set analysis of executives' individual and organizational characteristics. Human Resource Management., 58, 203-217.

BBC. (2018). D\&G: China shopping sites pull products in ad backlash. BBC News. Retrieved November 23, 2018 form https://www.bbc.com/news/business-46312844.

Chang, K., \& Cooke, F. L. (2015). Legislating the right to strike in China: Historical development and prospects. Journal of Industrial Relations, 57(3), 440-455.

Collinson, S., \& Liu, Y. (2019). Recombination for innovation: Performance outcomes from international partnerships in China. R\&D Management, 49(1), 46-63.

Dellestrand, H., \& Kappen, P. (2012). The effects of spatial and contextual factors on headquarters resource allocation to MNE subsidiaries. Journal of International Business Studies, 43(3), 219-243.

Dewhurst, M., Pettigrew, M., \& Srinivasan, R. (2012). How multinationals can attract the talent they need. McKinsey Quarterly, 3(8), 92-99.

Froese, F. J. (2009). Organizational expatriates and self-initiated expatriates: who adjusts better to work and life in Japan? The International Journal of Human Resource Management, 20(5), 1096-1112.

Froese, F. J. (2013). Work values of the new generation of business leaders in Shanghai, Tokyo and Seoul. Asia Pacific Journal of Management, 30, 297-315.

Froese, F. J., \& Kishi, Y. (2013). Organizational attractiveness of foreign firms in Asia: Soft power matters. Asian Business \& Management, 12(3), 281-297.

Froese, F. J., \& Xiao, S. (2012). Work values, job satisfaction and organizational commitment in China. The International Journal of Human Resource Management, 23(10), 2144-2162. 
Glaeser, E., Huang, W., Ma, Y., \& Shleifer, A. (2017). A real estate boom with Chinese characteristics. Journal of Economic Perspectives, 31(1), 93-116.

Govindarajan, V., \& Ramamurti, R. (2011). Reverse innovation, emerging markets, and global strategy. Global Strategy Journal, 1(3-4), 191-205.

Guest, P., \& Sutherland, D. (2009). The impact of business group affiliation on performance: Evidence from China's "national champions". Cambridge Journal of Economics, 34(4), 617-631.

Han, D. (2016). From vagueness to clarity? Articulating legal criteria of digital content regulation in China. Global Media and Communication, 12(3), 211-227.

Han, Z., \& Froese, F. J. (2010). Recruiting and retaining R\&D professionals in China. International Journal of Technology Management, 51(2/3/4), 387-408.

He, Y., Xu, Y., Pang, Y., Tian, H., \& Wu, R. (2016). A regulatory policy to promote renewable energy consumption in China: Review and future evolutionary path. Renewable Energy, 89, 695-705.

Herrigel, G., Wittke, V., \& Voskamp, U. (2013). The process of Chinese manufacturing upgrading: Transitioning from unilateral to recursive mutual learning relations. Global Strategy Journal, 3(1), $109-125$.

Hitotsuyanagi-Hansel, A., Froese, F. J., \& Pak, Y. S. (2016). Lessening the divide in foreign subsidiaries: The influence of localization on the organizational commitment and turnover intention of host country nationals. International Business Review, 25(2), 569-578.

Hofstede, G. (1980). Culture's consequences. New York: Sage Publications.

Hofstede, G. (1991). Cultures and organizations. London: McGraw-Hill.

House, R. J., Hanges, P. J., Javidan, M., Dorfman, P. W., \& Gupta, V. (2004). Culture, leadership, and organizations: The GLOBE study of 62 societies. Thousand Oaks: Sage.

Ingelhart, R. (1997). Modernization and postmodernization: Cultural, economic and political change in 43 societies. Princeton: Princeton University Press.

International Monetary Foundation (IMF). (2018). Gross Domestic Product. [Dataset]. Retrieved from [World Economic Outlook October 2018].

Kang, H., Shen, J., \& Benson, J. (2017). Not all expatriates are the same: Non-traditional South Korean expatriates in China. The International Journal of Human Resource Management, 28(13), 1842-1865.

Kemper, L., Bader, K., \& Froese, F. J. (2016). Diversity management in aging societies: A comparative study of medium to large corporations in Germany and Japan. Management Revue, 27(1/2), 29-49.

Kemper, L., Bader, K., \& Froese, F. J. (2019). Promoting gender diversity in a challenging environment: The case of Scandinavian subsidiaries in Japan. Personnel Review, 48(1), 56-75.

Kogut, B., \& Singh, H. (1988). The effect of national culture on the choice of entry mode. Journal of International Business Studies, 19(3), 411-432.

Kwon, J. (2012). Does China have more than one culture? Exploring regional differences of work values in China. Asia Pacific Journal of Management, 29(1), 79-102.

L'Oréal. (2017). 2017 annual report. https://www.loreal-finance.com/en/annual-report-2017/LOrea 1_2017_Annual_Report.pdf.

Leung, K. (2010). Beliefs in Chinese culture. In M. H. Bond (Ed.), The Oxford handbook of Chinese psychology (pp. 221-240). Oxford: Oxford University Press.

Lewin, A. Y., Kenney, M., \& Murmann, P. (2016). China's innovation challenge: Overcoming the middle-income trap. Cambridge: Cambridge University Press.

Li, F. (2019). Why have all west ern internet firms (WIFS) failed in china? A phenomenon-based research. Academy of Management Discoveries, 5(1), 13-37.

Li, J., Lee, R. P., \& Zhang, L. (2018). Managerial ties and knowledge transfer in business ecosystems: Evidence from Korean subsidiaries in China. Asian Business \& Management. https://doi. org/10.1057/s41291-018-0033-y.

Liu, Y. (2017). Born global firms' growth and collaborative entry mode: The role of transnational entrepreneurs. International Marketing Review, 34(1), 46-67.

Liu, Y., \& Almor, T. (2016). How culture influences the way entrepreneurs deal with uncertainty in interorganizational relationships: The case of returnee versus local entrepreneurs in China. International Business Review, 25(1), 4-14.

Liu, Y., \& Huang, Q. (2018). University capability as a micro-foundation for the Triple Helix model: The case of China. Technovation, 76-77, 40-50.

Liu, Y., \& Meyer, K. E. (2018). Boundary spanners, HRM practices, and reverse knowledge transfer: The case of Chinese cross-border acquisitions. Journal of World Business. https://doi.org/10.1016/j. jwb.2018.07.007. 
Liu, Y., \& Woywode, M. (2013). Light-touch integration of Chinese cross-border M\&A: The influences of culture and absorptive capacity. Thunderbird International Business Review, 55(4), 469-483.

Liu, Y., Öberg, C., Tarba, S. Y., \& Xing, Y. (2018). Brand management in mergers and acquisitions: Emerging market multinationals venturing into advanced economies. International Marketing Review, 35(5), 710-732.

Liu, Y., Sarala, R. M., Xing, Y., \& Cooper, C. L. (2017). Human side of collaborative partnerships: A microfoundational perspective. Group \& Organization Management, 42(2), 151-162.

Ma, X., Delios, A., \& Lau, C. M. (2013a). Beijing or Shanghai? The strategic location choice of large MNEs' host-country headquarters in China. Journal of International Business Studies, 44(9), 953-961.

Ma, S., Silva, M. G., Callan, V. J., \& Trigo, V. (2016). Control and commitment HR practices, job satisfaction and turnover intentions: A comparison between local and multinational firms in China. The International Journal of Human Resource Management, 27(9), 974-990.

Ma, X., Tong, T. W., \& Fitza, M. (2013b). How much does subnational region matter to foreign subsidiary performance? Evidence from Fortune Global 500 Corporations' investment in China. Journal of International Business Studies, 44(1), 66-87.

Miao, Y., Zeng, Y., \& Lee, J. Y. (2016). Headquarters resource allocation for inter-subsidiary innovation transfer: The effect of within-country and cross-country cultural differences. Management International Review, 56(5), 665-698.

Ministry of Commerce People's Republic of China (MOFCOM). (2019). MOFCOM Department of Foreign Investment Administration Comments on China's Absorption of Foreign Investment in January-December 2018. http://english.mofcom.gov.cn/article/newsrelease/policyreleasing/20190 $1 / 20190102827255$.shtml.

National Bureau of Statistics of China (NBSC). (2018). 1-8 Number of Business Entities by Region and Status of Registration 2017 [Dataset]. Retrieved from China Statistical Yearbook 2018.

Ning, L., Sutherland, D., \& Fu, X. (2017). Local context and innovation in China. Asian Business \& Management, 16(3), 117-129.

Pak, Y. S., Sun, Q., \& Yang, Y. (2019). Influences of expatriate management styles on host-country nationals' turnover intention. Asian Business \& Management. https://doi.org/10.1057/s4129 1-018-0047-5.

Puck, J. F., Holtbrügge, D., \& Mohr, A. T. (2009). Beyond entry mode choice: Explaining the conversion of joint ventures into wholly owned subsidiaries in the People's Republic of China. Journal of International Business Studies, 40(3), 388-404.

Schwartz, S. H. (1994). Beyond individualism/collectivism: New cultural dimension of values. In U. Kim, H. C. Trianidis, C. Kagitcibasi, S. C. Choi, \& G. Yoon (Eds.), Individualism and collectivism: Theory, method and applications (pp. 85-119). Thousand Oaks: Sage.

Singh, D., Pattnaik, C., Lee, J. Y., \& Gaur, A. (2019). Subsidiary staffing, cultural friction, and subsidiary performance: Evidence from Korean subsidiaries in 63 countries. Human Resource Management, 58(2), 219-234.

Sutherland, D. (2003). China's large enterprises and the challenge of late industrialisation. New York: RoutledgeCurzon.

Toplensky, R. (n.d.). Mergers enforcer rejects big reforms. Financial Times.

Tsang, E. W. (2002). Acquiring knowledge by foreign partners from international joint ventures in a transition economy: Learning-by-doing and learning myopia. Strategic Management Journal, 23(9), 835-854.

Tung, R. L. (2008). The cross-cultural research imperative: The need to balance cross-national and intranational diversity. Journal of International Business Studies, 39(1), 41-46.

Tung, R. L., Worm, V., \& Fang, T. (2008). Sino-Western business negotiations revisited-30 years after the China's Open Door Policy. Organizational Dynamics, 37(1), 60-74.

Volkswagen. (2017). Annual report 2017. https://annualreport2017.volkswagenag.com/group-manag ement-report/business-development/deliveries.html.

Wang, H., \& Liu, Y. (2016). Entrepreneurship and talent management from a global perspective: Global returnees. Cheltenham: Edward Elgar.

Warner, M. (2009). 'Making sense' of HRM in China: Setting the scene. The International Journal of Human Resource Management, 20(11), 2169-2193.

World Bank. (2019). World Development Indicators (WDI) [Dataset]. Retrieved from World Bank Open Data. 
World Bank \& Development Research Center of the State Council, the People's Republic of China (DRC). (2013). China 2030: Building a modern, harmonious, and creative society (English). Washington, DC: World Bank.

Wu, C., \& Burge, G. S. (2018). Competing for foreign direct investment: The case of local governments in China. Public Finance Review, 46(6), 1044-1068.

Xing, Y., Liu, Y., \& Cooper, C. L. (2018). Local government as institutional entrepreneur: Collaborative partnerships in fostering regional entrepreneurship. British Journal of Management, 29(4), 670-690.

Zeng, M. (2018). Smart business: What Alibaba's success reveals about the future of strategy. MA: Harvard Business Review Press.

Zeng, Y., Shenkar, O., Lee, S., \& Song, S. (2013). Cultural differences, MNE learning abilities, and the effect of experience on subsidiary mortality in a dissimilar culture: Evidence from Korean MNEs. Journal of International Business Studies, 44(1), 42-65.

Zhang, D., Cai, J., Dickinson, D. G., \& Kutan, A. M. (2016a). Non-performing loans, moral hazard and regulation of the Chinese commercial banking system. Journal of Banking \& Finance, 63, 48-60.

Zhang, M. M., McNeil, N., Bartram, T., Dowling, P., Cavanagh, J., Halteh, P., et al. (2016b). Examining the 'black box' of human resource management in MNEs in China: Exploring country of origin effects. The International Journal of Human Resource Management, 27(8), 832-849.

Zhang, H., Patton, D., \& Kenney, M. (2013). Building global-class universities: Assessing the impact of the 985 project. Research Policy, 42(3), 765-775.

Zhao, Z. J., \& Anand, J. (2013). Beyond boundary spanners: The 'collective bridge'as an efficient interunit structure for transferring collective knowledge. Strategic Management Journal, 34(13), 1513-1530.

Zhao, S., \& Du, J. (2012). Thirty-two years of development of human resource management in China: Review and prospects. Human Resource Management Review, 22(3), 179-188.

Zhou, C., \& Li, J. (2008). Product innovation in emerging market-based international joint ventures: An organizational ecology perspective. Journal of International Business Studies, 39(7), 1114-1132.

Publisher's Note Springer Nature remains neutral with regard to jurisdictional claims in published maps and institutional affiliations. 